\title{
THE AMERICAN SOCIETY FOR THEATRE RESEARCH
}

The American Society for Theatre Research (ASTR) was founded in 1956 to encourage theatre scholarship and to provide a link with other similar groups represented in the International

Federation for Theatre Research. The ASTR is the only American theatre organization affiliated with the American Council of Learned Societies and the International Federation for Theatre Research (IFTR/FIRT). In 1967 the ASTR was incorporated under the laws of New Jersey as a nonprofit corporation. In informal correspondence, the society is referred to as "ASTR."

Theatre Survey, the official journal of ASTR, is published bianually in May and in November. The ASTR annual meeting occurs in the fall of each year. Inquiries and communications for ASTR [other than membership (see inside front cover)] should be sent to

\section{Judy Wilmeth \\ Box 1897 \\ Brown University \\ Providence, RI 02912}

ASTR annual dues are $\$ 45$ for institutions and for nonmembers, $\$ 25$ for students, and $\$ 30$ for retirees; membership includes a subscription to Theatre Survey.

\section{OFFICERS AND EXECUTIVE COMMITTEE OF ASTR}

Thomas Postlewait, President (1994-97)

Gresdna Doty, Vice-President (1994-97)

Don B. Wilmeth, Secretary (1995-98)

Albert Wertheim, Treasurer (1994-97)

Rosemary K. Bank (1994-97)

Michael R. Booth (1993-96)

Sarah Bryant-Bertail (1994-97)

Marvin Carlson (1992-95)

Errol Hill (1993-96)

Margaret Knapp (1993-96)

Kim Marra (1994-97)

Janelle Reinelt (1993-96)

Joseph Roach (1992-95)

Virginia Scott (1992-95)

Ronald W. Vince (1994-97)

Barry Witham (1992-95)

\section{EX-OFFiCIO}

Sarah Blackstone, Richard M. Buck, Kalman A. Burnim, Phyllis T. Dircks, Joseph Donahue, Michal Kobiaika, Felicia Londré, Bruce McConachie, Cary Mazer, Tice L. Miller, Stephen M. Vallillo, Simon Williams, Don B. Wilmeth 

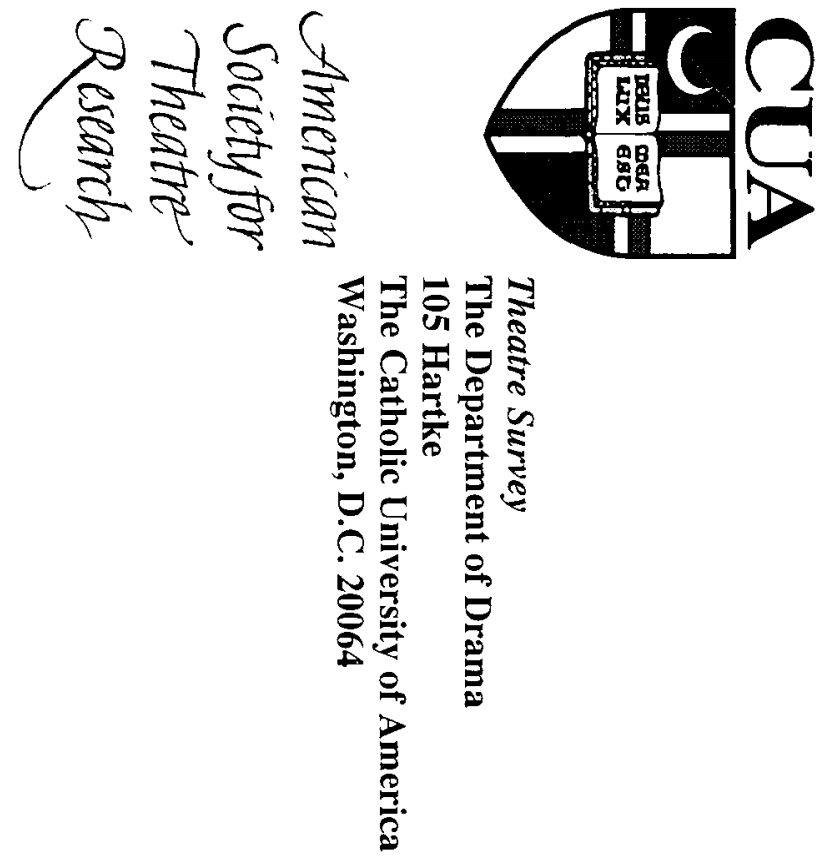

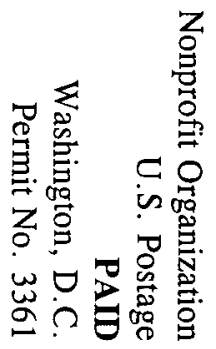

